\title{
Educational Leadership to Create Authentic Inclusive Schools: The Experiences of Principals in a Canadian Rural School District
}

\author{
Angela Irvine and Judy L. Lupart \\ University of Alberta \\ Tim Loreman \\ Concordia University College of Alberta \\ Donna McGhie-Richmond \\ University of Victoria
}

\begin{abstract}
Inclusive education - based on the premise of social justice-advocates equal access to educational opportunities for all students. This research provides insight into the inclusive experiences of school principals in a Canadian rural school district through quantitative and qualitative inquiries. A survey was administered to 16 school administrators, and following initial data analysis, individual interviews with four school principals were carried out as part of a multi-perspective case study of students with special needs. Overall, inclusion was viewed in a positive light and extended beyond classroom placement to meeting the needs of diverse groups of students within the regular classroom. The responsibilities and strategies of the principals that support inclusion are outlined and other factors that contribute to effective inclusion identified. Key factors include collaboration among key players in the students' education and opportunities for professional development. The results have implications for school leadership preparation and professional development of school administrators.
\end{abstract}

Traditionally, special needs programming has been provided in separate, special education programs, classrooms, and settings. Indeed, for the majority of Canadian provinces and territories special education services in schools have mushroomed since the 1960s and 1970s. In today's schools the challenge is to reverse this trend to ensure that all students have the opportunity to experience instruction and learning in the general classroom (Lupart, 2009). Numerous strategies have been advanced; however, most were based on faulty assumptions about the nature of disability (Skrtic, 1996). Advocates for inclusive education have come to the realization that the onus for change must shift from the individual student fitting into school programs offered to 
schools making the necessary changes to ensure learning success for all students. The question "does inclusion work?" is no longer the question to be asking (Pruslow, 2003). Instead, researchers and educators need to ask "what can be done to make inclusion work?" (Lupart, 2009).

The Canadian Charter of Rights and Freedoms (Government of Canada, 1982) enshrines children's right to participate in society, including educational settings. An emphasis on inclusion is evident in Canadian policies on persons with disabilities (Government of Canada, 2006), as well as provincial and territorial education legislation. However, placement of students with special needs in the inclusive classroom can cause tension for school administrators and classroom goals (i.e., the curriculum, differentiated instruction) can often clash with program goals (i.e., meeting individual student needs; Huefner, 1994; Philpott, 2007; Philpott \& Dibbon, 2007). There is some lack of agreement amongst administrators when the issue of "appropriate" education is at hand. There are often cost implications that need to be considered (Huefner, 1994; Pruslow, 2003). On the one hand, inclusion is more cost effective because students can attend their home school and do not require transportation to a different location; on the other hand, extra resources are typically required at the school for inclusion to be successful (Pruslow, 2003). Moreover, these issues persist beyond the instructional setting and into extracurricular school activities (Fetter-Harrot, Steketee, \& Dare, 2008). Academic activities must be balanced with nonacademic activities in order for schools to make the desired shift from instructional and physical mainstreaming to authentic inclusion.

Inclusion means that all students regardless of differences have their individual educational needs met in the general education classroom and school context (Andrews \& Lupart, 2000; Loreman, 1999). While there are many definitions and interpretations of "inclusion," few reflect the concept of "authentic inclusion." By this we mean that diversity is not situated in the student; it is also not about where a student is placed. Rather, diversity resides in the social and cultural practice, values, and beliefs that make up our Canadian society. Authentic inclusive classrooms reflect this understanding. All students should have access to these important concepts as well as the associated activities.

Though top-down initiatives, such as provincial legislation and policy, have been effective for setting the direction and for establishing a framework for educational change, it is ultimately the front-line professionals, regular classroom teachers, and school administrators who have the major responsibility for making inclusive education work (Lupart \& Webber, 2002). The school administration (i.e., principal and vice principal) can have a critical influence on the success of authentic inclusion in the community school (Lupart \& Porath, 2009).

\section{The Role of School Administrators}

Striving for authentic inclusion amidst the day-to-day tensions school administrators face is not an easy task. School principals, in particular, need to address multiple responsibilities within their school settings. Current literature frames the principal's role into three main categories: (a) leadership (Attfield \& Williams, 2003; Gameros, 1995; McClean, 2007), (b) mediation (Ryan, 2007), and (c) collaboration with parents and school staff (Villa, Thousand, Meyers, \& Nevin, 1996; Zaretsky, 2004). As the leaders in the schools, principals must ensure adequate staffing is in place, appropriate technology is available, and safety of both staff and students is maintained (McClean, 2007). Parental involvement allows the onus to fall not only on the school staff, but it helps ensure shared decision-making processes. Villa et al. (1996) found that these 
roles, particularly administrative support and collaboration, were indicators of positive attitudes among school staff toward inclusion, thus making inclusion more successful.

\section{Principal Perspectives on Inclusion}

Few research projects have focused on the perspectives of school administrators in inclusive settings and, of those studies that have, it is difficult to separate the administrator perspectives from other school staff (e.g., Belcher, 1995; Romano \& Chambliss, 2000). While some studies report positive influential administrator attitudes toward inclusion (e.g., Belcher, 1995; Stanovich \& Jordan, 1998), other studies represent inclusion in a very different light —one that defines inclusion as a complex concept that, when put into practice, can be hindered by several difficulties (e.g., lack of resources and support staff; Crockett, Myers, Griffin, \& Hollandsworth, 2007). School administrators believed that their work lives became more complex when they were faced with the task of including students with exceptional needs. They reported having expanded responsibilities, increased demands from the teaching staff, and heightened accountability (Crockett et al., 2007). Other concerns about the inclusion of students with special needs in regular school settings were the impact on general education teachers and students as well as the impact on the students with special needs (Keaster, Melville, \& Miller, 1999). For example, Crockett et al. (2007) found that principals were concerned that inclusion provided both the special education and general education students with fewer opportunities to learn. In addition, the principals believed that the students with typical needs felt that there was an increased pressure to achieve because the inclusion of students with exceptional needs required more teacher attention and a disproportionate amount of resources being allocated toward these students. As a result of this increased pressure on students, parents in this study objected to inclusion as they feared it would negatively impact their children's learning.

Grider (1995) reported similar attitudes toward inclusion in his school study. After interviewing parents, teachers, and school principals, it was found that none of the respondents favoured serving students exclusively in the regular classroom. Instead, other forms of educating students with exceptional needs (e.g., pull-out programs or special education classrooms) were preferred. Caution should be noted, however, in the interpretation of these findings given the early date of most articles and in the fact that the studies were carried out mainly in U.S. schools.

Recent studies, in contrast, have reported more neutral attitudes toward inclusion. A study of principals' perspectives of inclusion in elementary school settings (see Salisbury, 2006) found that schools with strong administrative support and commitment were able to effectively serve more students with exceptional needs in general education for a greater percentage of time. Similarly, Loreman (2001) found that principal attitudes and actions were a decisive factor in the successful inclusion of children of varied ages and disabilities. Principals in support of inclusion provided their staff with the supports deemed necessary to succeed in an environment where no possibility of 'opting out' of inclusion was the norm (i.e., additional resources, planning time, and training). Indeed, Stanovich and Jordan (1998) found that principal attitudes and beliefs about heterogeneous classrooms was the strongest predictor of effective teaching practices in inclusive classrooms. The school principal's support for inclusion appears to be a significant determining factor in creating effective inclusive settings.

Two possible explanations for the differing perspectives on inclusion are identified in the current inclusion literature: (a) the differences among rural, suburban, and urban communities and (b) the differences between elementary and secondary schools (Romano \& Chambliss, 
2000). In many rural communities, regular classroom placement is the only option available to students; thus, inclusion is a more natural "fit." Also, the curriculum in elementary schools tends to be inherently flexible allowing for more modifications and accommodations as compared to the more rigid secondary curriculums. Knowing these contextual features are possible determinants for school inclusion, it would seem that some school administrators have been effective in introducing strategies to overcome these challenges. This study examines school administrator factors in elementary and secondary schools in a Canadian rural school district where inclusion has been the guiding norm for over 10 years.

\section{Rationale for the Study}

Inclusive education proponents advocate for equal access to educational opportunities for all students regardless of physical, intellectual, emotional, or learning disability. All students, regardless of individual difference, learn together in regular schools that adapt and change the way they work in order to meet the needs of all (Foreman, 2001; Loreman \& Deppeler, 2001; Lupart, McKeough, Porath, Phillips, \& Timmons, 2009; Sailor \& Skrtic, 1995). To be successful, inclusion requires commitment from governments, teacher-preparation institutions, schools, the community, and, most importantly, individual teachers and administrators. The administrator perspective has been typically overlooked in most studies on inclusion. Because there is a growing emphasis on the principal's leadership and involvement in creating a school context that supports inclusion, we felt it was important to explore administrator roles in a district that is highly committed to inclusion.

While inclusion was historically based more on ideals and values than research (Foreman, 2001), there is a growing body of research and literature which points to the efficacy of inclusion (e.g., Copeland et al., 2002; Deshler et al., 2002; McDonnell et al., 2003; Ritter, Michel, \& Irby, 1999). There is a need for further research, especially research of a qualitative nature (Hunt \& Goetz, 1997; Nietupski, Hamre-Nietupski, Curtin, \& Shrikanth, 1997). This need was highlighted in key studies in the mid-1990s (Hunt \& Goetz, 1997; Nietupski et al., 1997) where findings revealed a striking absence of participatory qualitative research on inclusive education. Only $1.2 \%$ of the research reported in 785 articles between 1976 and 1995 addressed inclusion through qualitative research. While more qualitative research has been added to the literature since that time, many questions remain to be addressed. As Hunt and Goetz (1997) argued:

The potential for participants to actively contribute to understanding of inclusion practices is great, particularly given the multiple stakeholders who are involved; indeed, participatory research methods may redefine both the research questions that are asked and the traditional role of the researcher... (p. 25)

The current study used mixed methods, situated within both qualitative and quantitative research paradigms. Our overarching research project extends beyond the perspectives of administrators and includes the viewpoints and opinions of all stakeholder groups. However, for the purposes of this paper, only principal perspectives are reported. The quantitative component reflects the input of all administrators (i.e., who chose to participate in the survey study) associated with a particular school district, and provides numerical data to test and validate hypotheses about how inclusive education practices occur in a western Canadian rural school district. The qualitative analysis embellishes the quantitative data by focusing in-depth on 4 of the principals' 
experiences with inclusion. In addition, the strong qualitative aspect contributes to theory and educational practice in line with Sailor and Skrtic's (1995) argument that

...we need research that promotes understanding of how teachers interpret their practices in context, how those interpretations affect their practice, and the manner in which they change...A postmodern study of education transformations thus would seem to require a constructivistic approach, one grounded in qualitative or interpretivist research methods... (p. 421)

Waite, Bromfield, and McShane (2005) echoed the need for more qualitative research on inclusive education practices and suggested that when evaluating an inclusive education program a reliance solely on quantitative data is inappropriate. Quantitative research presents some of the perspectives on some of the issues of inclusion, while qualitative research supports and extends these ideas.

To this end, a study employing both qualitative and quantitative methodologies is both timely and important if the philosophical position that inclusion is an issue of social justice and is practically possible in schools is to be supported. As Canadian provinces and school districts move toward more inclusive educational systems it becomes increasingly important to identify and describe factors that contribute to the success of inclusion.

\section{The Rural School District}

As the primary focus of the data collection for this project, the research team chose a school district located in rural central Alberta to better understand the experiences students with exceptionalities have in the school setting and to further explore the educational practices that are present in this district. The district encompasses 18 schools and over 4200 students with a wide range of school settings varying from a 12-student Hutterite Colony to a composite high school with an enrolment of over 800 students. The district has an anecdotal history of successful inclusive practices for students with exceptional needs and has no ongoing regional special education programs in place. Instead, all students are taught and supported in the regular classroom setting. It is district policy that the individual needs of all students be the first priority when providing education. Individual student needs are met through initiatives such as family support and partnerships, provision of appropriate resources, administrative support, extra planning time, and a 'school-based resource team' in each school. Inclusion in the district not only relies on the school-based supports; rather, the entire community is called upon for assistance and resources.

The school district has adopted a unique approach to distribution of its government allocation of special-needs funding. First, an amount of funding is withheld at the central office to provide services to schools (i.e., such as consulting) and in contrast to other districts' practices, schools are not asked to contribute on a 'fee for service' basis. The district believes this removes the disincentive for schools to access these services for budgetary reasons. In addition, rather than providing special education funding only to those students who qualify for it, the district divides the total amount of extra funding and provides these funds to schools based on the size of their total student population. It is made explicit that these funds are to be used to support the learning of any students who require extra provisions whether they formally qualify for funding or not. Those who qualify for funding on the basis of a severe special need are allocated an additional amount provided for them by the government on an individual basis. In this way, the district believes it does a better job of supporting the learning needs of all students, while at the 
same time making specific provisions in the event of the presence of a student with a severe special need.

\section{Research Methodology}

\section{Quantitative Methods}

Instrumentation. All administrators (both principals and vice principals) in the district were invited to complete a modified, online version of the Diversity, Differentiated Instruction and Development Survey (DIDDs) for administrators (Lupart, Whitley, Odishaw, \& McDonald, 2006). Modifications to the original survey were made based on feedback from the district staff and a focus group of university experts regarding clarity and relevant terminology. In total there were 63 survey items rated on a 5-point Likert scale (i.e., strongly disagree, disagree, neither agree or disagree, agree, and strongly agree). The survey items were ordered according to the random number chart and "reverse code" items were included.

Sample. Responses were received from nine schools in the district. Sixteen administrators (i.e., principals and vice principals), representing $80 \%$ of all administrators in the district, completed the DIDDs survey. While this is a modest number of surveys, the high response rate indicates excellent representativeness of the data. The Kaiser-Meyer-Oklin Index (Kaiser, 1970; 1974) of this survey demonstrated a high level of sampling adequacy at .572. However, because of the modest number of surveys, no demographic data was used in the analysis as it is unlikely that any meaningful conclusions could be drawn and there is high likelihood that the participants could be identified. It is known that administrators in the district are generally highly experienced educators. It is also important to note that while the focus of this paper is on principal perspectives, the quantitative data includes survey data from both principals and vice principals. Within this district, principals and vice principals work as a close collaborative team and demonstrate overlap in duties and flexibility in their roles. For example, a vice principal in this district will often take on the responsibilities of the principal should the principal be unavailable because of other responsibilities or events in the school or community. While we cannot assume that principals and vice principals hold the same attitudes toward inclusion, the quantitative data is used as a "starting point" to further understand the perspectives of school principals in inclusive settings.

Analysis. In an attempt to establish a meaningful number of comprehensive items a principal components analysis (data reduction) was completed. Items were selected based on the magnitude of individual item load in the varimax rotated component. It is important to note that each item in this analysis loaded significantly on only one subscale to allow for simple, unidimensional interpretation (Thurstone, 1947). In addition, Cronbach's alpha was calculated to measure internal validity and the reliability of the items. Analysis was then conducted with respect to responses on each of the identified factors.

\section{Qualitative Methods}

Paradigmatic background. Qualitative researchers tend to believe that reality is a construct created by individuals interacting with those around them (Merriam, 1998). Therefore, the 
constructivist paradigm was chosen as the most appropriate guide for this project. Social constructions are usually shared among individuals, thus making them more real (Merriam, 2002). In the qualitative research arena, meaning is mediated through the researchers' perceptions and their interactions with the participants that constitute the inquiry. The researchers must explore and search for how the participants interpret their experiences and what meaning they attribute to these experiences. This does not mean that multiple realities cannot exist simultaneously. Different realities can exist side-by-side because they are mental constructs that do not represent "real" in its true form. The success of the inquiry is not dependent on the identification of what is "real;" rather, it is judged based on increased understanding of the phenomenon being studied. A qualitative inquiry is considered reliable when others agree that the researchers' interpretations make sense and are dependable (Merriam, 2002).

Sample. The participants in the qualitative component of the study represented four schools in the district. These schools were part of a broader research study on inclusive education. Students identified as having exceptional needs based on the Alberta Education Special Education Coding Criteria were chosen as focus participants for case studies examining successful inclusive practices. The exceptionalities represented in this sample of students included autism, mild cognitive disabilities, global developmental delay, and gifted/talented. Each student was provided with individualized education through an Individualized Program Plan (IPP) and received formal educational services to assist them with their learning. Once the focus students were identified, all "key players" in the students' education (i.e., parents/guardian, program assistants, teachers, school administrators/principals, school support staff, peers, and district administrators) were contacted and asked to participate as informants for the case studies. For the purposes of this paper, the focus of the qualitative inquiry was on the principals of the four participating schools in an attempt to gain an understanding of their experiences as leaders within their schools and their perspectives regarding the inclusion of students with exceptionalities. Of the four principals participating in this component of the study, two were administrators in elementary school settings (i.e., kindergarten to Grade 6), one was an administrator in a junior high/high school (i.e., grades 7 to 12), and one was an administrator at a kindergarten through Grade 12 school.

Interview methods and analysis. Each principal took part in an audiotaped, openended, semi-structured interview focused on the inclusive practices in their schools and the specific inclusive experiences of the focus student. The interview questions served as a guide to focus the interview while at the same time giving the participants the freedom to explore and recollect their own personal experiences. Following each interview, all audiotapes were transcribed verbatim and the transcripts were sent to the participants to be checked for clarity and accuracy. At this point, the principals could also add any information that may have been missed during the formal interview. After member checks were completed all transcripts were uploaded into NVIVO 8 for data organization and coding. A thematic analysis (Kvale, 1996), in which the researchers were the "miners" searching for meaning, was completed and common themes and trends within and across interviews were identified. Following theme identification, the researchers revisited the data in an attempt to make sense of the "stories" and accurately represent the perspectives of the school principals. 


\section{Results}

\section{Quantitative Data}

Components of inclusive education. The 63 Likert-scale items of the original DIDDs survey for principals underwent data reduction (i.e., principal components analysis) to establish a smaller meaningful number of comprehensive items (25) designed to capture the nomological network associated with inclusive education practices in Canadian schools from an administrator's perspective. Item selection for the final scale was based on the magnitude of individual item loadings as seen in the varimax rotated component matrix, with the added criteria that each item load significantly on only one subscale to facilitate a simple, unidimensional interpretation (Thurstone, 1947). Strong loadings typically in the 0.70 to 0.90 region were evident. An examination of the resulting Scree plot (Catell, 1966) revealed the presence of seven components. A final evaluation of each item included in the scale was verified by researcher understanding of the conceptual and practical aspects of inclusive education practices from the perspective of administrators.

Scale validation is supported by a final factor structure characterized by a highly significant correlation between nearly all intrafactor items. Notably, the seven-component solution explained a total of $84.43 \%$ of the total variance (Component $1=32.11 \%$; Component $2=$ 12.23\%; Component $3=10.40 \%$; Component $4=9.98 \%$; Component $5=7.59 \%$; Component 6 $=7.17 \%$; Component $7=4.87 \%$ ). Mean scores for each factor and for individual items retained in the factors are presented in Table 1 (higher scores represent more positive responses). A high level of sampling adequacy (i.e., Kaiser-Meyer-Oklin Index $=0.572$; Kaiser 1970, 1974) and highly significant measure of sphericity-Bartlett's (1954) Test of Sphericity $\left(\chi_{(190)}^{2}=328.2\right.$, prob. $=<0.001$ ) - was evident, further supporting both the approach taken (principal components analysis with varimax rotation) and the suitability of the items selected to characterize the scale construct.

The internal validity of the seven-component factor solution as measured by Cronbach's alpha (Cronbach, 1951) was 0.89. Reliabilities for the seven subscales ranged between 0.71 and 0.89 , exceeding the generally accepted level of 0.70 , validating the legitimacy of the individual components of the total scale. The mean score for the entire scale was calculated at 4.00 , suggesting an overall positive view of the district inclusive environment.

Factor One addresses feelings of ownership and responsibility for inclusion in the school. Factor Two captures the essence of a supportive school team. Factor Three is about being prepared and willing to adapt instruction to promote inclusion. Factor Four accounts for administrator beliefs and promotion of inclusion and diversity. Factor Five addresses pragmatic issues with respect to the implementation of inclusive education. Factor Six addresses student responsibility and self-esteem, and Factor Seven addresses issues regarding the parent-school team. When asked about parental involvement in their schools, about half of the principals stated that fewer than a quarter of parents assisted in classroom activities or school events with only one reporting school involvement from over $50 \%$ of parents.

Almost all of the administrators surveyed took part in some form of professional development activities. These activities represented a wide array of professional development opportunities including administrator in-services and workshops, workshops at their schools' Professional Development Days, individual study, the annual Teacher's Convention, and other conferences focused on topics of particular interest. 
Table 1

Mean Scores of Items and Factors from the Administrator Survey

\begin{tabular}{|c|c|c|}
\hline Item & Mean & SD \\
\hline Factor One: Administrator Ownership and Responsibility & 4.00 & 0.77 \\
\hline 33: Generally, there is good cooperation this year among administrators (if more than 1). & 3.94 & 1.06 \\
\hline $\begin{array}{l}\text { 34: I have engaged in meaningful informal professional development (internet chat, discussions } \\
\text { with colleagues) in order to develop inclusive practice. }\end{array}$ & 4.00 & 1.03 \\
\hline 44: I am responsible for making the school more inclusive. & 4.00 & 0.89 \\
\hline $\begin{array}{l}\text { 59: I have attended adequate professional development activities (courses, workshops) outside of } \\
\text { my school in order to develop inclusive practice. }\end{array}$ & 3.67 & 0.87 \\
\hline Factor Two: The School Team & 3.98 & 0.73 \\
\hline 2: I do not have suitable instructional materials to support the students in my school. (reversed) & 4.06 & 0.77 \\
\hline 8: The school has an efficient system for reporting absences and discovering reasons for it. & 4.00 & 1.00 \\
\hline 10: Generally there is good cooperation this year between teachers and parents. & 4.25 & 0.74 \\
\hline 13: School staff agree about the ways to discipline children who break rules. & 3.62 & 0.64 \\
\hline Factor Three: Preparedness and Adaptability & 4.00 & 0.66 \\
\hline 6: Materials are appropriately adapted for students with special needs (e.g., large print or Braille). & 4.00 & 0.66 \\
\hline $\begin{array}{l}\text { 9: Including students with special needs in the regular classroom takes away from the education } \\
\text { of other students. (reversed) }\end{array}$ & 3.80 & 1.08 \\
\hline 19: Teachers should spend more time on drill and memorization. (reversed) & 4.07 & 1.10 \\
\hline 61: I encourage students to celebrate difference rather than conformity. & 4.13 & 0.52 \\
\hline Factor Four: Valuing and Promoting Student Diversity & 3.89 & 0.58 \\
\hline $\begin{array}{l}\text { 11: The curriculum materials used at my school reflect the background and experience of all stu- } \\
\text { dents. }\end{array}$ & 3.81 & 0.65 \\
\hline $\begin{array}{l}\text { 36: I believe inclusion provides students with special needs the opportunity to reveal their learning } \\
\text { potential. }\end{array}$ & 4.25 & 0.45 \\
\hline 37: I encourage students to explore views which are different from their own. & 4.25 & 0.45 \\
\hline 46: I do not involve students in formulating school rules. (reversed) & 3.25 & 1.18 \\
\hline Factor Five: Implementation & 3.38 & 0.67 \\
\hline $\begin{array}{l}\text { 14: My school needs more professional development activities in the area of inclusive education. } \\
\text { (reversed) }\end{array}$ & 2.94 & 1.00 \\
\hline 15: Labelling of some students can separate them from others in the classroom. & 3.00 & 0.89 \\
\hline 51: Discipline problems are generally dealt with in the classroom. & 4.19 & 0.43 \\
\hline Factor Six: Student Responsibility and Self-Esteem & 4.08 & 0.59 \\
\hline 29: Students do not always feel safe at this school. (reversed) & 3.96 & 0.87 \\
\hline 52: Students in my school are encouraged to take responsibility for their own learning. & 4.16 & 0.66 \\
\hline 57: I encourage all students to have high aspirations about their learning. & 4.38 & 0.50 \\
\hline Factor Seven: The Parent-School Team & 4.44 & 0.51 \\
\hline 5: There are few opportunities for parents to become involved in the school. (reversed) & 4.12 & 0.81 \\
\hline 18: Developing a supportive school community is as important as raising academic achievement. & 4.44 & 0.63 \\
\hline 28: I do not greatly value the knowledge that parents have about their children. (reversed) & 4.75 & 0.50 \\
\hline
\end{tabular}

\section{Qualitative Data}

The qualitative data yielded several key themes that demonstrated the day to day activities and beliefs about administrator roles and responsibilities in inclusive education, as well as their beliefs and attitudes about inclusion itself. The actions of the administrators supported not only the student but teachers, parents, and community members as well. 
Definitions of inclusion. Throughout the discussions of inclusive practices several components of the principals' definitions of inclusion became apparent. First, inclusion was identified as the "new normal," in other words, according to the principals inclusion is what people now expect to find in schools:

It [inclusion] has become so normal for people. We always used to talk about normalization. What is normal? If they don't see inclusion as a threat then it's normalized in mind. That's what I am hoping you find in your interviews is that people don't see it as a threat. If they don't see it is as a threat it's become normal and then we have succeeded.

In addition, the principals viewed inclusion as more than an issue of physical placement. One principal recounted his experience including a student with severe disabilities:

It was to give her that social aspect of just being with other people, with other kids, just even being pushed around the school. Just to be normal throughout our peers, semi-normal. And there's nothing wrong with that. That was just an expectation. It wasn't just to stick her in one room all day and watch movies.

Instead, inclusion was focused on providing educational opportunities and meeting all students' needs through individualized supports. It was noted by one principal that "Every child will struggle at some point and so we ensure that there's support; people support, mostly, in place for those children." Another aspect of the principal's definitions of inclusion was that it occurs in a context that supports student diversity. As one administrator asserted, "[Our school] is, I think, a model of inclusion. We have lots of children within our school with lots of different ability levels and strengths and weaknesses."

Students with special needs have emotions and desires just like the rest of the students. Within this diversity context all students are treated with respect. In some cases we heard administrators affirm that the need for respect applies to all individuals who are part of the school. For example, one administrator said, "Treat everyone with respect whether it's [this student] with special needs or [Mr. X], who is a teacher in our school."

Another school principal focused on similarities between students rather than diversity. To this principal inclusion was about being "like everyone else." While this statement appears to conflict with other definitions, the remaining conversation with this administrator suggested that being "like everyone else" included having the same opportunities as other students and being treated with respect.

Finally, a third aspect of the administrators' definitions of inclusion was that inclusion is often a "rural necessity:"

At [town A] you have the elementary and the junior/senior high and [at town B] you have the junior/senior high. That's the two pockets; and then you have the rural schools that surround them and like I said earlier small schools it is the only way to exist. The larger schools have to work towards it.

Many small communities do not have access to specialized programs or advanced special education services. However, when this rural necessity was described, inclusion was always represented in a positive light.

School principals' philosophies. Throughout the interviews the researchers queried the principals regarding their leadership and inclusion policies. Many of the schools in the district take part in a virtues program where students are taught about virtues and values. The principals 
talked about this program frequently and stated that they believed in this type of education as well as having an inclusive ideology ingrained in their school practices. As one administrator put it, "I believe in values based instruction, and our school has developed, I guess, various statements which are supportive of that philosophy which also supports inclusion in order for their culture to be successful." Another school principal reported that for such inclusive ideology to be put into practice the teaching staff had to live their schools' mission statements. In support, yet another principal recalled, "There was one fellow who said that a mission is not what you see on the wall, it is what you feel when you walk in the hall. And I have never forgot that." As a broader philosophy, but still related to inclusive ideology, some of the school principals discussed the importance of valuing all students:

I really believe that all kids can learn and can do well given supports and encouragement and having, knowing that they're valued individuals and a part of the bigger society which in this case would be the school or the classroom.

Collaboration. Collaboration was discussed as necessary to the success of inclusion. Three types of collaboration were described in the principal interviews: (a) communication with the parents, (b) collaboration within the school, and (c) collaboration with the community. Communication with parents was viewed as essential to student success. As one principal informed, "[It's] very critical to have the parent. They have to really know what's going on, and have to approve it because they'll come back and say, 'Well, I didn't know that was going to happen." The frequency of contact between parents of children with special needs and their teachers varied greatly. One family contacted the school staff on a daily basis while another family only communicated with school staff monthly. Overall, the school principals desired more contact with the parents. One principal expressed the concern that "generally, though, it's a struggle even just to get a parent to come to an IPP meeting, really hard."

Several methods of communication were used to encourage, support, and maintain open communication with parents. Formal meetings such as Parent Council meetings or IPP meetings often brought parents into the schools and provided a forum to express opinions and concerns. Furthermore, newsletters were distributed to inform parents and encourage their involvement in the school setting:

When we're studying virtues, we send home information for parents because we believe the primary place they need to be taught is in the home. We're supporting the home. We're supporting the home and teaching those values and those virtues [that we teach at the school].

In other cases, special events increased parental visits to the schools. Finally, the parents were provided with opportunities to volunteer in the school setting, thus encouraging them to be more present in the school setting.

Collaboration within the schools involved three types of relationships: (a) collaboration between teachers, (b) collaboration between teachers and program assistants, and (c) collaboration between school administrators and teaching staff. The principals reported that within their schools, teachers communicated and cooperated with each other to provide support and advice as colleagues. Sometimes one teacher would have expertise or skills to share with other staff members:

As a team, as a staff, right at the beginning of the year we talk about teacher strengths and what are our areas that we can help kids in.... We are very cognizant that even as a staff we all have 
areas where we're more expert at than other areas. But there's someone within our building that is an expert on everything we need to have.

In addition, regular collaboration between the teachers and the program assistants was essential in ensuring that the educational program ran smoothly. To this end, a principal noted, "We have weekly meetings with teachers and with program assistants so that the teachers can filter down to the program assistants what is happening."

As the third form of collaboration in the schools, the principals discussed how communication with their colleagues and teaching staff served as a form of support for them as well as a means to develop effective strategies. This relationship was expressed by an administrator who stated, "It's nice to be able to talk with my co-workers, my vice principal....because you bounce off each other. [You] sort of got that, different teams: teacher-admin, small admin group."

Support that is external to the school by way of collaboration with the community was named as an invaluable asset to inclusive practices. Support from community members and cooperation with school programs assisted the schools in better serving the students with exceptional needs:

You take work experience...I go up and down Main Street and I can't think of a business that hasn't taken a special student at some point or another. Provided that they are aware of the limitations... and whether there is supervision here.

Community collaboration provides the students with exceptionalities with a richer educational experience tailored to their needs within and beyond school.

Role of principals. A large part of the conversations with the school principals was focused on the role they play in inclusive education and what they thought a school administrator's responsibilities were. The school principals viewed it as their role to create an inclusive atmosphere in their school. One principal stated that "I think my primary role is for staffing. It was getting people that will be hired that are prepared to live that [inclusive] philosophy." They reported that their main responsibility was to provide leadership and guidance in the school setting so inclusion could be practiced effectively and successfully. For one administrator this involved "facilitating those discussions, those communications, pointing people in the right direction for further training and making, ensuring that there's communication between all parties including the parents."

Facilitating the inclusive practices and providing opportunities for the school staff to hone their skills was viewed as resulting in a determined and skillful teaching staff. The principals recognized that sometimes the teaching staff would need encouragement to try new methods and the school principals saw it as their responsibility for motivating them:

The world is different every year, so use it. But it's the same lesson plans year after year. It bothers me. But there are some people who have overheads, and they'll use those same overheads every year. But as a principal, you try and kick them in the butt and say you got to change a little bit but... hopefully... you have to nudge them I guess.

Principals identified ways of providing the teachers with support in their inclusive teaching endeavors:

Touching base, walking in the classroom, seeing how things are going and making sure they know that they can come and talk to you if things aren't working well and they know they can go talk to 
the special needs teacher or coordinator, etc. Just again, making sure that all the doors are always open... not feeling isolated.

Principal supports. Two supports were raised as important in supporting the school principals in their role: (a) knowledge of available supports and (b) professional development opportunities. Knowing where to find resources or "knowing who to call" allowed the school principals to be more confident in their role. It gave them access to information when required and allowed them to provide more effective leadership and support to the teaching staff. Professional development opportunities further enhanced the principals' ability to provide leadership and guidance in that it provided them with new ideas as well as affirmation that he/she is doing "the right thing:"

I attend conferences on special needs once every couple of years. It's really nice to hear this is what we should be doing....I go to pick up ideas and when I hear what should be done and the benefits, we've experienced all that already.

The school principals also reported relying on support from school staff, colleagues, and parents. Communicating with the school staff alerted the principals to what was going on in the school setting and provided them with opportunities to "bounce ideas off" of the teachers and support staff:

At the school level, it's nice to have staff that come in and talk about things...feel that you're approachable...share things, which sort of clues you in on what's going on, which is great. It's nice to be able to talk with my co-workers, my vice principal... because you bounce off each other.

Support external to the school was cited as important to the principals. Again, the principals reported they would "bounce ideas off" of fellow administrators and inquire about how things are done in other schools:

Bouncing ideas off of people and that's inter-school, too. So another principal at another school might have a child who has similar characteristics and I'll say, what do you do?...Having built those relationships so that you can call people and reflect with them and think and brainstorm and reassure yourself that you're doing the right stuff. That's the most important thing.

Finally, support from the parents was viewed as an important source of support for the school principals. As one principal noted, "I have been here long enough that I am able to enjoy tremendous support from parents."

Distribution of funding. All of the school principals in this study stated that distribution of funds was a "balancing act" for them. There was not sufficient funding for them to acquire all of the desired resources or support, therefore, compromises were made and priorities placed:

It is always a balancing act because the parents believe that because there is provincial funding for special needs that they have the right to one-on-one. Where the reality of it is that it barely covers two on one.... I have directed the business manager to look at a balance where every high needs coded student that we get, we would hire a program assistant.

School principals regarded program assistants (i.e., educational assistants) to be essential to successful inclusion. Funds were spent in hiring an adequate number of program assistants to meet student needs: 
The first thing we always...budget for, is staffing and so we get our teachers in place and then we ensure there is program assistants in place and make sure that there is enough program assistant support for kids with different needs.

For one of the principals, making choices about the distribution of funds was made easier because of the practice of site-based management of funds. The principal was free to choose where his or her priorities were and how the school's money would be spent. This sense of freedom allowed this principal to make the decisions considered to be most beneficial to the staff and students in the school.

\section{Discussion}

The quantitative and qualitative results that emerged in this study explored the experiences, opinions, and challenges of prinicipals working within schools that held and practiced inclusive policies. In general, the experiences of the principals were positive. Some of these attitudes may be attributed to the rural setting in which these schools were situated. For the rural school district principals in this study inclusion is a "normal" component of the educational system. Many small communities have no alternatives to including students with exceptional needs in the general education classroom. According to the principals, however, this reality is regarded to be a positive attribute of rural schooling. In contrast, other studies (e.g., Huefner, 1994; Philpott, 2007; Philpott \& Dibbon, 2007; Pruslow, 2003) conducted in urban settings explored alternative programs such as segregated classrooms, pull-out programs, or special schools in which you may find varying opinions and experiences of inclusion when compared to a school board with inclusive philosophies embedded in it as the only approach. Romano and Chambliss (2000) acknowledged this difference while examining inclusion in urban, suburban, and rural districts and stated that the inclusive experiences in each setting can be very different.

Five of the seven factors identified in the survey data were also reflected in the qualitative inquiries (see Table 2). For example, analyses of the quantitative data identified administrative ownership and responsibility, the school team, preparedness and adaptability, valuing and promoting student diversity, and the parent school team as important factors for successful inclusion. The themes emerging from the principal interviews reflected the administrator's roles and responsibilities, collaboration within the schools, adapting the individual students' programs to meet the students' needs, valuing all students within a diverse environment, and the importance of parental communication and involvement. Professional development for principals was also recognized as an important component to successful inclusive practices in both sets of data. Fifteen of the 16 principals surveyed reported participation in some form of professional development activities. Similarly, professional development was cited as an important support during the interviews. Finally, both the quantitative and qualitative inquiries revealed the need, the benefit, as well as the challenge in securing parental involvement in school activities. Survey results showed that half of the administrators reported that only $25 \%$ of the parents in their schools took part in classroom activities. Only one principal stated that more than half of the parents were involved in their school's activities. Similarly, in the qualitative interviews the school principals expressed a desire for more parents to become involved in their children's education as they viewed the parents' role as an important one on the "learning team."

The principals in this study viewed inclusion as extending beyond physical placement in the regular education classroom. Inclusion entailed individualized programming and support for all students. The philosophies of the principals in this project were revealed to be student-centred 
Table 2

Comparison of Quantitative and Qualitative School Administrator Data

\begin{tabular}{|c|c|}
\hline $\begin{array}{l}\text { Factors of Effective Inclusive Practices } \\
\text { (Quantitative Survey Data) }\end{array}$ & $\begin{array}{c}\text { Emerging Concepts within Themes } \\
\text { (Qualitative Interview Data) }\end{array}$ \\
\hline Factor One: Administration Ownership and Responsibility & $\begin{array}{l}\text { Administrator's roles and responsibilities-the need for sup- } \\
\text { portive motivating leadership }\end{array}$ \\
\hline Factor Two: The School Team & Collaboration within the school \\
\hline Factor Three: Preparedness and Adaptability & $\begin{array}{l}\text { Individualized programming to meet students' diverse } \\
\text { needs }\end{array}$ \\
\hline Factor Four: Valuing and Promoting Student Diversity & $\begin{array}{l}\text { Inclusion is about valuing all students within a diverse envi- } \\
\text { ronment }\end{array}$ \\
\hline Factor Five: Implementation & -- \\
\hline Factor Six: Student Responsibility and Self-Esteem & -- \\
\hline Factor Seven: The Parent School Team & $\begin{array}{l}\text { The importance of parental involvement and communica- } \\
\text { tion }\end{array}$ \\
\hline
\end{tabular}

and primed to meet the needs of all students rather than just those who have exceptional needsa finding that was found to be in line with the overall support and positive attitudes toward inclusion in the survey study. In this way, diversity in the classroom is not viewed as a deficit inherent in students, but rather as part of the 'norm' reflective of our communities and society in general. Diversity can be seen as providing opportunity for the principals in this study to "live their mission statement" and value all students. The district-wide virtues program appears to also support the school district in its goal towards authentic inclusion wherein all students have their needs met in accepting, respectful, diverse settings that mirror the diversity inherent in society.

The beliefs and practices of the principals in this school district appear to support current effective schools literature (Marzano, 2003). It was widely perceived by the principals that their role is to provide supportive, motivating leadership while upholding inclusive principles (Attfield \& Williams, 2003; Gameros, 1995; McClean, 2007). This finding aligns with those reported by Salisbury (2006), Loreman (2001), and Stanovich and Jordan (1998), in that the role of the principal is one of leader and mentor for the rest of the "key" players in the students' education. It is important to note that these administrators are working within a district that has made "inclusion" the essential framework for instruction and learning in the district, so these results may be biased toward inclusive practice. Nevertheless, the principals stated a significant need for support from the teaching staff, colleagues, and parents as well as opportunities for professional development. Beyond these supports, there was a need for collaboration, a key component also indentified in previous reports (Villa et al., 1996; Zaretsky, 2004). Collaboration puts the onus on the "learning team" (i.e., administrators, teachers, program assistants, parents, and, at times, the student) and not solely on the principal.

The district's funding model was cited as supportive of an inclusive approach. While still a "balancing act," the flexibility that the principals experienced in funding allocation, in their view, allowed them to focus resources on meeting the needs of all students within their schools. The principals in this study said they focused on providing expertise in each school to support teaching and learning needs. Program support and professional development opportunities were prominent resources deemed necessary to support inclusion and student learning needs. This is an important finding given the ambiguity about the professional needs of principals and the temptation to underscore the importance of professional development (Wright, da Costa, \& Peters, n.d.). 
Collaboration clearly underpins inclusive practice in this school district. The presence of school-based teams in each school, provision of program support, and efforts to communicate and include parents as well as the community support this school district's mission: 'Together we learn.' Despite some challenges in gaining desired parental involvement, several strategies, such as newsletters, special events, and volunteer opportunities, were used to encourage more parent involvement and interaction. The school principals were unequivocal in raising the necessity of communication and collaboration between all key players (i.e., administrators, teachers, support staff, and parents) to facilitate effective inclusion. They provided opportunities for their staff to meet regularly for instructional purposes. In support, collaboration has been identified as a significant contributing factor in other studies examining inclusion (Edmunds, Macmillan, Specht, Nowicki, \& Edmunds, 2009; Salisbury, 2006; Stanovich \& Jordan, 1998).

The collective results suggest that there are more benefits than drawbacks when the role of administrators immersed in an inclusive district is examined. This perception was displayed in both the quantitative and qualitative data thus suggesting these results and strategies may be carried over to other school boards. There are some results that map on to existing results and some that have not yet been reported in the literature.

\section{Limitations and Future Research}

While the sample from which this data was drawn is relatively small, the complementary nature of the data suggests that the interpretations are trustworthy. The small sample precludes comparison among the administrators at elementary, middle, and secondary levels. Future research should examine the beliefs and practices of school administrators in other rural school districts in Canada and other countries that are committed to inclusion to add to the research base and for point of comparison.

\section{Contributions and Implications for Practice}

This research study uncovered administration-related reasons for the reported success of a rural school district that is operating a district-wide program of inclusive education. The mixed methods design comprising both quantitative survey data as well as qualitative interview data lends validity to the findings. This investigation represents a contribution to knowledge in terms of the usefulness of these findings for future improvement for other rural school districts in Canada. The study highlights practices that the district will continue, along with areas that need to be improved upon, providing them with a rationale for action. Other jurisdictions wishing to emulate the approach of this school district have a basis from which they can begin to formulate policy and change practice within schools and classrooms.

There is a paucity of empirical research highlighting 'best practice' in inclusion across larger school jurisdictions, especially those in rural areas, and particularly with respect to administration. Indeed, we are not aware of any other similar study involving school administrators in rural Canada. One of the most important contributions of this research is that it may help rural school districts to move forward with practice that is informed by research evidence as opposed to intuition or 'trial and error.' 


\section{References}

Andrews, J., \& Lupart, J. L. (2000). The inclusive classroom: Educating exceptional children (2nd ed.). Scarborough, ON: Nelson Canada.

Attfield, R., \& Williams, C. (2003). Leadership and inclusion: A special school perspective. British Journal of Special Education, 30, 28-33.

Bartlett, M. S. (1954). A note on the multiplying factors for various chi square approximations. Journal of the Royal Statistical Society, 16(Series B), 296-298.

Belcher, R. N. (1995, March). Opinions of inclusive education: A survey of New Mexico teachers and administrators. Paper presented at the American Council on Rural Special Education Conference, Las Vegas, NV: American Council on Rural and Special Education.

Catell, R. B. (1966). The Scree test for number of factors. Multivariate Behavioural Research, 1, 245276.

Copeland, S. R., McCall, J., Williams, C. R., Guth, C., Carter, E. W., Fowler, S. E., et al. (2002). High school peer buddies: A win-win situation. Teaching Exceptional Children, 68(1), 16-21.

Crockett, J. B., Myers, S. T., Griffin, A., \& Hollandsworth, B. (2007). The unintended side effects of inclusion for students with learning disabilities: The perspectives of school administrators. Learning Disabilities: A Multidisciplinary Journal, 14, 155-166.

Cronbach, L. J. (1951). Coefficient alpha and the internal structure of tests. Psychometrika, 16, 297-334.

Deshler, D. D., Schumaker, J. B., Marquis, J., Bulgren, J. A., Lenz, B. K., Davis, B., et al. (2002). The educational context and outcomes for high school students with disabilities: A case study comparing the school life of students with disabilities and their peers without disabilities. Kansas City, KS: Kansas University.

Edmunds, A. L., Macmillan, R. B., Specht, J., Nowicki, E. A., \& Edmunds, G. (2009). Principals and inclusive schools: Insight into practice. Journal of Educational Administration and Foundations, 20(1), 1-23.

Fetter-Harrot, A., Steketee, A. M., \& Dare, M. (2008). Boosting inclusion for students with disabilities. District Administration, 44, 63-65.

Foreman, P. J. (2001). Integration and inclusion in action (1st ed.). New South Wales: Harcourt Brace \& Company.

Gameros, P. (1995). The visionary principal and inclusion of students with disabilities. NASSP Bulletin, $79,15-17$.

Government of Canada. (1982). Charter of rights and freedoms. Retrieved February 16, 2010, from http://laws.justice.gc.ca/en/charter/index.html.

Government of Canada. (2006). Advancing the inclusion of persons with disabilities. Retrieved February 16, 2010, from www.hrsdc.gc.ca/en/disability_issues/reports/fdr/2006/advancinginclusion.pdf.

Grider, J. R. (1995). Full inclusion: A practitioner's perspective. Focus on Autistic Behavior, 10, 1-11.

Huefner, D. S. (1994). The mainstreaming cases: Tensions and trends for school administrators. Education Administration Quarterly, 30, 27-55

Hunt, P., \& Goetz, L. (1997). Research on inclusive educational programs, practices, and outcomes for students with severe disabilities. Journal of Special Education, 31(1), 3-29.

Kaiser, H. (1970). A second generation Little Jiffy. Psychometrika, 35, 401-415.

Kaiser, H. (1974). An index of factorial simplicity. Psychometrika, 39, 31-36.

Keaster, R. D., Melville, G. A., \& Miller, J. H. (1999). Administrators' attitudes and the change process: Indication for inclusive education. Journal of At-Risk Issues, 6, 5-12.

Kvale, S. (1996). Interviews: An introduction to qualitative research interviewing. Thousand Oaks, CA: Sage Publications.

Loreman, T. (1999). Integration: Coming from the outside. Interaction, 13(1), 21-23.

Loreman, T. (2001). Secondary school inclusion for students with moderate to severe disabilities in Victoria, Australia. Unpublished doctoral dissertation, Monash University, Victoria, Australia. 
Loreman, T. J., \& Deppeler, J. (2001). Inclusive education in Victoria: The UNESCO Education for All 2000 Assessment. Interaction, 14(2\&3), 13-17.

Lupart, J. L. (2009). The challenge of student diversity in Canadian schools. In J. L. Lupart, A. McKeough, M. Porath, L. Phillips, \& V. Timmons (Eds.), The challenges of student diversity in Canadian schools: Essays on building a better future for exceptional children (pp. 15-27). Markham, ON: Fitzhenry and Whiteside.

Lupart, J. L., McKeough, A., Porath, M., Phillips, L., \& Timmons, V. (2009). The challenges of student diversity in Canadian schools: Essays on building a better future for exceptional children. Markham, ON: Fitzhenry and Whiteside.

Lupart, J. L., \& Porath, M. (2009). Building a better future for Canadian students. In J. L. Lupart, A. McKeough, M. Porath, L. Phillips, \& V. Timmons (Eds.), The challenges of student diversity in Canadian schools: Essays on building a better future for exceptional children (pp. 1-14). Markham, ON: Fitzhenry and Whiteside.

Lupart, J. L., \& Webber, C. (2002). Canadian schools in transition: Moving from dual education systems to inclusive schools. Exceptionality Education Canada, 12(2\&3), 7-52.

Lupart, J. L., Whitley, J., Odishaw, J., \& McDonald, L. (2006). Whole school evaluation and inclusion: How elementary school participants perceive their learning community. In C. Dionne \& N. Rousseau (Eds.), Transformation of educational practices: Research on inclusive education (pp. 113143). Quebec, QC: Presses de l'Universite du Quebec.

Marzano, R. J. (2003). What works in schools: Translating research into practice. Alexandria, VA: Association for Supervision and Curriculum Development.

McClean, W. A. (2007). An investigation into the need for effective leadership mechanisms in the management of a successful inclusive programme in the primary school system. Online submission. (ERIC Document Reproduction Service No. ED500461). Retrieved February 16, 2010, from http://www.eric.ed.gov/ERICWebPortal/search/detailmini.jsp?_nfpb=true\&_\&ERICExtSearch_S earchValue $0=$ ED500461\&ERICExtSearch SearchType $0=$ no\&accno=ED500461

McDonnell, J., Thorson, N., Disher, S., Mathot-Buckner, C., Mendel, J., \& Ray, L. (2003). The achievement of students with developmental disabilities and their peers without disabilities in inclusive settings: An exploratory study. Education and Treatment of Children, 26(3), 224-236.

Merriam, S. B. (1998). Qualitative research and case study applications in education: Revised and expanded from case study research in education. San Francisco: Jossey-Bass.

Merriam, S. B. (2002). Qualitative research in practice: Examples for discussion and analysis. San Francisco: Jossey-Bass.

Nietupski, J., Hamre-Nietupski, S., Curtin, S., \& Shrikanth, K. (1997). A review of curricular research in severe disabilities from 1976 to 1995 in six selected journals. Journal of Special Education, $31(1), 36-55$.

Philpott, D. (2007). Assessing without labels: Inclusive education in the Canadian context. Exceptionality Education Canada, 17(3), 3-34.

Philpott, D., \& Dibbon, D. (2007). A review of the literature on Newfoundland and Labrador's model of student support services: A global perspective on local practice (Appendix G, literature review), Focusing on students: A report of the ISSP \& Pathways Commission (pp. 177-219). St. John's, NL: ISSP \& Pathways Commission.

Pruslow, J. T. (2003). What school administrators should know about inclusion and its costs. Leadership and Policy in Schools, 2, 65-78.

Ritter, C. L., Michel, C. S., \& Irby, B. (1999). Concerning inclusion: Perceptions of middle school students, their parents and teachers. Rural Special Education Quarterly, 18(2), 10-16.

Romano, K., \& Chambliss, C. (2000). K-12 teachers' and administrators' attitudes toward inclusive educational practices. (ERIC Document Reproduction Service No. ED443215).

Ryan, J. (2007). Dialogue, identity, \& inclusion: Administrators as mediators in diverse school contexts. Journal of School Leadership, 17, 340-370. 
Sailor, W., \& Skrtic, T. M. (1995). American education in the postmodern era. In L. Paul, D. Evans, \& H. Rosselli (Eds.), Integrating school restructuring and special education reform (1st ed., Vol. 1, pp. 214-236). Orlando, FL: Brace Coll.

Salisbury, C. L. (2006). Principals' perspectives on inclusive elementary schools. Research and Practice for Persons with Severe Disabilities, 31, 70-82.

Skrtic, T. M. (1996). School organization, inclusive education, and democracy. In J. Lupart, A. McKeough, \& C. Yewchuk (Eds.), Schools in transition: Rethinking regular and special education (pp. 81-118). Scarborough, ON: Nelson.

Stanovich, P., \& Jordan, A. (1998). Canadian teachers' and principals' beliefs about inclusive education as predictors of effective teaching in heterogeneous classrooms. Elementary School Journal, 98, 221-238.

Thurstone, L. L. (1947). Multiple factor analysis. Chicago: University of Chicago Press.

Vidovich, D., \& Lombard, T. P. (1998). Parents', teachers', and administrators' perceptions of the process of inclusion. Educational Research Quarterly, 21, 41-52.

Villa, R. A., Thousand, J. S., Meyers, H., \& Nevin, A. (1996). Teacher and administrator perceptions of heterogeneous education. Exceptional Children, 63, 29-45.

Waite, S. J., Bromfield, C., \& McShane, S. (2005). Successful for whom? A methodology to evaluate and inform inclusive activity in schools. European Journal of Special Needs Education, 20(1), 71-88.

Wright, L., da Costa, J., \& Peters, F. (n.d.). Learning and problematizing principal professional practice through action research. Retrieved February 16, 2010, from http://www.allacademic.com//meta/p_mla_apa_research_citation/2/7/4/5/0/pages274507/p274507 $-1 . p h p$.

Zaretsky, L. (2004). Advocacy and administration: From conflict to collaboration. Journal of Educational Administration, 42, 270-286.

\section{Authors' Note}

Correspondence concerning this article should be addressed to Judy Lupart, Professor, University of Alberta, 6-102 Education North, Edmonton, AB, T6G 2 G5.

Email: judy.lupart@ualberta.ca. 